\title{
Combined effects of the implementation of magnesium and ascorbic acid on myocardial ischemia-reperfusion in open heart surgery
}

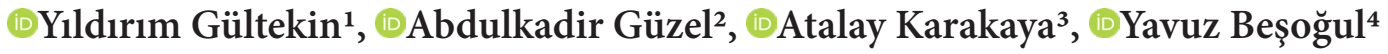 \\ ${ }^{1}$ Kırıkkale University, School of Medicine, Department of Cardiovascular Surgery, Kırıkkale, Turkey \\ ${ }^{2}$ Beylikdüzü State Hospital, Department of Cardiovascular Surgery, İstanbul, Turkey \\ ${ }^{3}$ İstanbul Medipol University, Bağcllar Mega Hospitals Complex, Department of Cardiovascular Surgery, İstanbul, Turkey \\ ${ }^{4}$ Eskişehir Osmangazi University, School of Medicine, Department of Cardiovascular Surgery, Eskişehir, Turkey
}

Cite this article as: Gültekin Y, Güzel A, Karakaya A, Beşoğul Y. Combined effects of the implementation of magnesium and ascorbic acid on myocardial ischemia-reperfusion in open heart surgery. Anatolian Curr Med J 2021; 3(4); 319-326.

\begin{abstract}
Aim: This study aimed to investigate the combined effects of magnesium $(\mathrm{Mg})$ and high dose ascorbic acid on cardiac ischemiareperfusion (IR) injury.

Material and Method: This study was performed on 45 patients that were scheduled for coronary artery bypass graft (CABG) operations. The patients were divided into three equal groups. Group C received $50 \mathrm{mg} / \mathrm{kg}$ ascorbic acid; Group CM received the same dose of ascorbic acid plus $30 \mathrm{mg} / \mathrm{kg} \mathrm{Mg}$; Group $\mathrm{K}$ received neither ascorbic acid nor $\mathrm{Mg}$. At various times during the operation, the blood levels of malondialdehyde (MDA), serum creatine kinase $\mathrm{MB}(\mathrm{CK}-\mathrm{MB})$, and lactate dehydrogenase (LDH) levels were analyzed.

Results: There were statistically significant decreases in arrhythmia requiring intervention in Group CM compared to Group K $(\mathrm{P}=0.026)$. MDA levels increased in all groups but MDA 2 and MDA 3 levels were found to be statistically significantly lower in Group C and Group CM than in Group K ( $\mathrm{P}=0.009, \mathrm{P}=0.012, \mathrm{P}=0.009$ and $\mathrm{P}=0.006$ respectively). However, inhibition of lipid peroxidation in both Group C and Group CM was not parallel to cardiac enzymes and hemodynamic measurements. There was no significant statistical difference in the cardiac enzyme levels between Group K, Group C, and Group CM (p>0.05).

Conclusion: To reduce the IR, $\mathrm{Mg}$ with a high dose of ascorbic acid may be efficacious in patients undergoing cardiac surgery. A larger population group is needed to prove the results of this study.

Keywords: Open heart surgery, ascorbic acid, magnesium, ischemia-reperfusion
\end{abstract}

\section{INTRODUCTION}

Coronary artery bypass graft (CABG) surgery is one of the preferred treatments for ischemic heart disease. Despite advances in anesthesia techniques, myocardial preservation methods, and surgical techniques, myocardial IR injury is still one of the most significant causes of mortality and morbidity in cardiac surgery (1). Cardiopulmonary bypass (CPB) and cardioplegic arrest have some disadvantages, such as, systemic inflammatory response, myocardial damage, neurological damage, and renal and pulmonary insufficiency. Despite these disadvantages, the most important advantage of $\mathrm{CPB}$ is the ability to reach the target vessels in the immobile, hollow heart and to perform complete revascularization by working in a bloodless environment (2).
Normalization of myocardial blood flow after CPB, which is ischemic due to coronary artery disease, may result in IR injury. The degree of IR damage depends on the duration of the ischemic period and the degree of oxidative stress that occurs during reperfusion. The physiopathological mechanisms underlying IR injury are completely unknown (3). However, it has been suggested that excessive production of free oxygen radicals (FOR) and intracellular calcium (Ca) overload or redistribution may be the cause (4). IR damage presents clinically as microvascular dysfunction including myocardial stunning, reperfusion arrhythmia, myocyte death, endothelial dysfunction, and inadequate flow (5). 
Different pharmacological treatments have been tried to reduce myocardial IR damage and these can be classified into several categories. However, it is true that the choice of treatment, the method of administration, and the timing, i.e., before ischemia, before reperfusion, immediately after, or hours after reperfusion, is a critical issue (6).

Antioxidants are substances that delay or prevent the oxidation of substrates. Since FOR are constantly formed in normal metabolism, all aerobic cells develop protective mechanisms against their harmful effects. Antioxidants either play a preventive role by removing the FOR precursors from the environment and deactivating the catalysts, or they act by breaking the oxidation reaction chain that has started (7). Ascorbic acid (vitamin C) with its hydrophilic structure is an important antioxidant in both plasma and cytosol (8).

Calcium is an essential cation for normal cell metabolic functions. Calcium and FOR mechanisms are not separate, but two aspects of the same mechanism. While FOR cause membrane dysfunction and $\mathrm{Ca}$ redistribution, $\mathrm{Ca}$ accumulation may increase the damage initiated by FOR and even facilitate FOR production (9). It has been shown that Ca channel blockers are beneficial with various mechanisms of action in myocardial IR injury. Magnesium $(\mathrm{Mg})$ is a physiological Ca antagonist and cell membrane stabilizer. Together with $\mathrm{Ca}$ and phospholipids, Mg plays an important role in the regulation of cell permeability. It replaces $\mathrm{Ca}$ competitively in its binding sites and simultaneously inhibits Ca's entry into the cell, while speeding up its exit from the cell (10).

In this study, we aimed to compare the effectiveness of the use of a high dose of ascorbic acid in reducing myocardial IR damage with the effectiveness obtained by adding Mg to ascorbic acid.

\section{MATERIAL AND METHOD}

This prospective study was carried out on 45 patients with coronary artery disease who were scheduled to undergo CABG operations at the Department of Cardiovascular Surgery, Faculty of Medicine Osmangazi University. This study was conducted in accordance with the 1964 Declaration of Helsinki and subsequent changes or comparable ethical standards. All the patients participating in the study signed the informed consent form, and the study was carried out with the permission of Scientific Researches Ethics Committee of Osmangazi University Faculty of Medicine (Date: 30.06.2009, Decision No: 60).

Patients whose physical characteristics conformed to class I, II, or III according to the New York Heart Association (NYHA) classification and who were between the ages of 44 and 75 (mean: 63.86 \pm 8.59 ) with an ejection fraction (EF) of $40 \%$ or above, were included in the study. Patients who had myocardial infarction in the last six weeks, required emergency surgery and had previous cardiac surgery were excluded from the study. Patients who were known to be using $\mathrm{Ca}$ channel blockers or medication known to have antioxidant properties prior to the operation, were not included in the study. These antioxidant drugs are trimetazidine, statins, angiotensin-converting enzyme (ACE) inhibitors, $\mathrm{N}$-acetyl cysteine (NAC), xanthine oxidase inhibitors, vitamins ( $\alpha$-tocopherol (Vit E), $\beta$-carotene (Pro-vit A), pyridoxal-5-phosphate ), folic acid, nitric oxide donors (L-arginine), endothelin-1 receptor antagonists (bosentan), glucose-insulin-potassium (GIK) solutions, platelet inhibitors and adenosine. The patients were divided into three equal groups of 15 patients. The patients were randomly placed in groups and were not selected in terms of distribution of coronary artery lesions, ventricular function, age, gender, body surface area (BSA), NYHA class, or EF. While one of the groups was followed as the control group (Group K), Group C received $50 \mathrm{mg} /$ $\mathrm{kg}$ intravenous (IV) ascorbic acid (Vitabiol C $500 \mathrm{mg}$ ampoule, IE Ulagay, İstanbul, Turkey) after induction. Group CM was given $50 \mathrm{mg} / \mathrm{kg}$ IV ascorbic acid and $30 \mathrm{mg} /$ kg IV Mg (Magnesium Sulphate Biofarma 15\% Ampoule, Biofarma, Mamak, Ankara) after induction. Preoperative routine tests were performed for the surgery, and none of the patients had undergone CABG surgery before. The same team performed all operations and the operation time, $\mathrm{CPB}$ time, cross clamp (CC) time and the number of bypass grafts applied were recorded.

\section{Surgical Technique}

Standard premedication and anesthetic methods were used for all patients. Diazepam $10 \mathrm{mg}$ tb was given the night before the operation. When the patients were taken into the operating theatre, electrocardiography (ECG) monitoring was initiated and monitored (Datex-Ohmeda S/5, Datex-Ohmeda Inc., Madison, WI, USA) throughout the operation. At the same time, ECG segment analysis was performed for ischemia monitoring. Anesthesia induction was completed with $8 \mathrm{cg} / \mathrm{kg}$ fentanyl, $0.15 \mathrm{mg} /$ $\mathrm{kg}$ midazolam, and $0.1 \mathrm{mg} / \mathrm{kg}$ pancuronium bromide, after $1 \mathrm{mg} / \mathrm{kg}$ IV lidocaine was administered to reduce the hemodynamic response to laryngoscopy and endotracheal intubation at the beginning of induction. Maintenance of anesthesia was accomplished by infusion of $5-10 \mathrm{cg} / \mathrm{kg} /$ hour fentanyl and inhalation of $0.2-1.5 \%$ isoflurane plus $50 \%$ air-oxygen mixture. The neuromuscular blockade was maintained with the addition of $0.05 \mathrm{mg} / \mathrm{kg}$ pancuronium bromide to the pump reservoir at the beginning of the $\mathrm{CPB}$, and the termination of the isoflurane inhalation. A median sternotomy was performed on all patients, and heparinization was applied so that the activated coagulation time (ACT) was above 400 seconds before CPB started. 
During the operation, arterial cannulation was performed from the ascending aorta, and venous cannulation was performed from the right atrial appendage with a twostage cannula. All cardioplegia doses were administered antegrade through the cannula placed in the aortic root. $\mathrm{CPB}$ was performed on all patients by nonpulsatile perfusion (Terumo $^{\circ}$ Advanced Perfusion System 1, Terumo Medical Corporation, Ann Arbor, Michigan, USA), with a membrane oxygenator (Capiox SX $18 \mathrm{R}^{\circ}$, Terumo Medical Corporation, Somerset, NJ, USA). At the onset of $\mathrm{CPB}$, mild systemic hypothermia was applied to all patients until the temperature reached $28^{\circ} \mathrm{C}$. Intermittent hyperkalemic cold blood cardioplegia was used for myocardial protection. Before the CC was lifted, $10 \mathrm{ml} /$ $\mathrm{kg}$ hot-shot application was applied to provide controlled reperfusion. The presence of arrhythmia was noted at the beginning of the re-contractions of the heart after the removal of the CC. During the operation, no medication known to have an antioxidant effect was administered to the patients. Heparin neutralization was achieved with a $1.3 / 1$ protamine sulfate infusion after $\mathrm{CPB}$ was terminated.

To evaluate the hemodynamics of the patients, mean arterial pressure and heart rate were recorded before incision, before $\mathrm{CPB}$, five minutes after protamine infusion and at the postoperative second hour. In addition, patients who needed perioperative inotropes were recorded.

Arterial blood samples taken for an MDA level were taken at the following times: before induction (1), just before the cross clamp was lifted (2), and five minutes after the end of the protamine infusion (3). Plasma MDA determination was performed by applying the Esterbauer method which is based on a spectrophotometric measurement at a wavelength of $532 \mathrm{~nm}$. The color intensity of the complex formed by thiobarbituric acid, one of the degradation products of lipid peroxidation, was measured and results were reported in $\mathrm{nmol} / \mathrm{g}(11)$.

Venous blood samples were taken preoperatively and two hours after the operation for CK-MB and LDH levels.

\section{Statistical Analysis}

All statistics were performed using SPSS (Statistical Package for Social Science) version 15.0 for Windows (IBM Corporation, New York, USA). Data was summarized as mean \pm standard deviation (mean \pm std). The compliance of the data to normal distribution was tested with ShapiroWilk. ANOVA (analysis of variance) was used to determine the difference in group averages. The Tukey test, one of the POSTHOC tests, was used to determine the means between the different groups. Only the Kruskal-Wallis test was used to compare the NYHA class between the groups, and Fischer's exact test was used to compare the presence of arrhythmia. The $\mathrm{p}<0.05$ was considered statistically significant.

\section{RESULTS}

There was no statistically significant difference between the three groups in terms of demographic and preoperative data $(\mathrm{P}>0.05)$. The data are shown in Table 1.

\begin{tabular}{|lcccc|}
\hline Table 1. Demographic data of patients & $\begin{array}{c}\text { Group K } \\
(\mathbf{n}=15)\end{array}$ & $\begin{array}{c}\text { Group C } \\
(\mathbf{n}=15)\end{array}$ & $\begin{array}{c}\text { Group CM } \\
(\mathbf{n}=15)\end{array}$ & $\begin{array}{c}\mathbf{P} \\
\text { value }\end{array}$ \\
\hline Age (years) & $64.3 \pm 8.8$ & $66.7 \pm 7.4$ & $60.6 \pm 9.5$ & $>0.05$ \\
Gender (M / F) & $8 / 3$ & $8 / 2$ & $8 / 2$ & $>0.05$ \\
BSA $\left(m^{2}\right)$ & $1.77 \pm 0.16$ & $1.85 \pm 0.19$ & $1.84 \pm 0.14$ & $>0.05$ \\
NYHA(I/II/III) & $0 / 8 / 2$ & $2 / 7 / 1$ & $1 / 8 / 1$ & $>0.05$ \\
EF $(\%)$ & $46.5 \pm 10.7$ & $49.5 \pm 11.5$ & $47.0 \pm 4.21$ & $>0.05$ \\
\hline
\end{tabular}

BSA: Body surface area; NYHA: New York Heart Association; EF: ejection fraction

There was no statistically significant difference between the three groups in terms of intraoperative data $(\mathrm{P}>0.05)$. The data are shown in Table 2.

\begin{tabular}{|c|c|c|c|c|}
\hline & $\begin{array}{c}\text { Group K } \\
(\mathrm{n}=15) \\
(\mathrm{mean} \pm \text { std })\end{array}$ & $\begin{array}{c}\text { Group C } \\
(\mathrm{n}=15) \\
(\text { mean } \pm \text { std })\end{array}$ & $\begin{array}{c}\text { Group CM } \\
(n=15) \\
(\text { mean } \pm \text { std })\end{array}$ & $\begin{array}{c}P \\
\text { value }\end{array}$ \\
\hline $\begin{array}{l}\text { Operation time } \\
\text { (min) }\end{array}$ & $358.0 \pm 55.9$ & $351.0 \pm 55.6$ & $315.0 \pm 57.2$ & $>0.05$ \\
\hline $\begin{array}{l}\text { CPB time } \\
(\mathrm{min})\end{array}$ & $127.2 \pm 39.4$ & $132.9 \pm 32.1$ & $125.6 \pm 33.1$ & $>0.05$ \\
\hline $\begin{array}{l}\text { CC time } \\
(\mathrm{min})\end{array}$ & $70.9 \pm 26.9$ & $85.0 \pm 28.2$ & $81.4 \pm 23.1$ & $>0.05$ \\
\hline $\begin{array}{l}\text { Bypass grafts } \\
\text { count }\end{array}$ & $3.7 \pm 0.4$ & $3.8 \pm 0.4$ & $3.5 \pm 0.8$ & $>0.05$ \\
\hline
\end{tabular}

Preoperative CK-MB (CK-MB1) and postoperative CKMB (CK-MB 2) levels, preoperative LDH (LDH1) and postoperative $\mathrm{LDH}(\mathrm{LDH} 2)$ levels of the groups are shown in Table 3. In all three groups, the levels obtained in the second hour postoperatively for $\mathrm{CK}-\mathrm{MB}$ and $\mathrm{LDH}$ increased significantly compared to preoperative level $(\mathrm{P}<0.001)$. There was no significant difference between the groups in preoperative and postoperative CK-MB and LDH levels $(\mathrm{P}>0.05)$. However, although not statistically significant, both enzyme levels were found to be lower in Group CM than in Group K and Group C (Figures 1 and 2).

\begin{tabular}{|c|c|c|c|c|}
\hline & $\begin{array}{c}\text { Group K } \\
(n=15) \\
(\operatorname{mean} \pm \text { std }\end{array}$ & $\begin{array}{c}\text { Group C } \\
(n=15) \\
(\text { mean } \pm \text { std })\end{array}$ & $\begin{array}{c}\text { Group CM } \\
(n=15) \\
(\text { mean } \pm \text { std })\end{array}$ & $\begin{array}{c}P \\
\text { value }\end{array}$ \\
\hline $\begin{array}{l}\text { CK-MB } 1 \\
(\mathrm{~m} / \mathrm{l})\end{array}$ & $16.90 \pm 4.05$ & $17.80 \pm 6.32$ & $17.30 \pm 4.59$ & $>0.05$ \\
\hline $\begin{array}{l}\text { CK-MB } 2 \\
(\mathrm{~m} / \mathrm{l})\end{array}$ & $64.00 \pm 8.30^{*}$ & $73.10 \pm 19.89^{*}$ & $69.32 \pm 15.43^{\star}$ & $>0.05$ \\
\hline $\begin{array}{l}\mathrm{LDH} 1 \\
(\mathrm{~m} / \mathrm{l})\end{array}$ & $418.2 \pm 124.3$ & $486.2 \pm 114.1$ & $497.8 \pm 182.7$ & $>0.05$ \\
\hline $\begin{array}{l}\mathrm{LDH} 2 \\
(\mathrm{~m} / \mathrm{l})\end{array}$ & $992.1 \pm 225.1^{*}$ & $1013.0 \pm 306.9^{*}$ & $1037.2 \pm 256.6^{*}$ & $>0.05$ \\
\hline
\end{tabular}




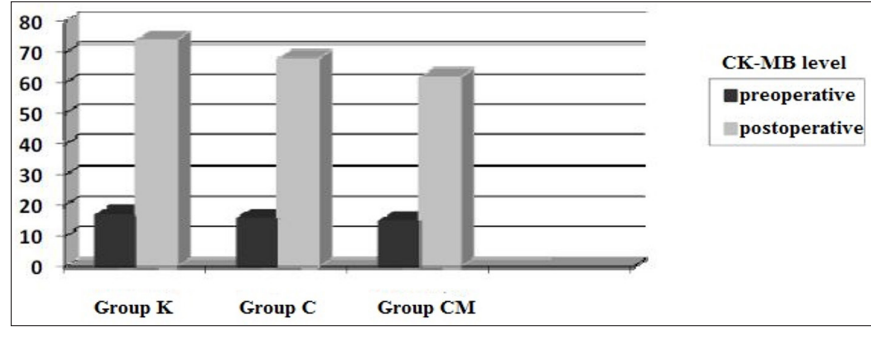

Figure 1. Preoperative and postoperative CK-MB levels in the groups. (When compared with the preoperative values of the postoperative values within the group, $\mathrm{P}<0.001$ ).

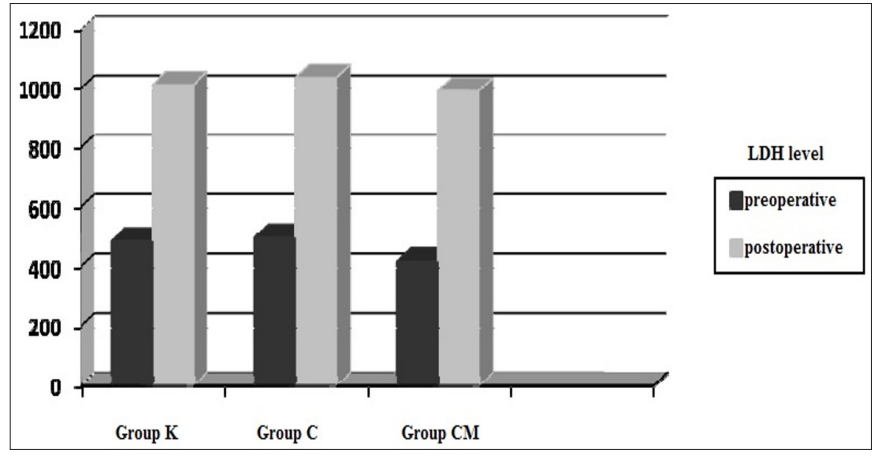

Figure 2. Preoperative and postoperative LDH levels in the groups. (When compared with the preoperative values of the postoperative values within the group. $(\mathrm{P}<0.001))$.

Preoperative and perioperative MDA level are shown in Table 4 and Figure 3. In Group K, MDA 2 and MDA 3 value were statistically significantly higher than the MDA 1 value $(\mathrm{P}=0.011$ and $\mathrm{P}=0.007)$. When Group $\mathrm{C}$ and Group CM's MDA value were compared within the group, no statistically significant difference was found ( $\mathrm{p}>0.05)$. MDA 2 and MDA 3 value were found to be statistically significantly lower in Group C and Group CM than in Group K ( $\mathrm{P}=0.009$, $\mathrm{P}=0.012, \mathrm{P}=0.009$ and $\mathrm{P}=0.006$ respectively)

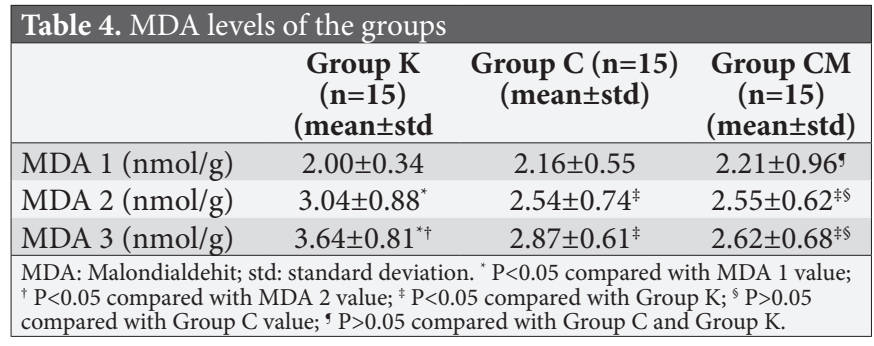

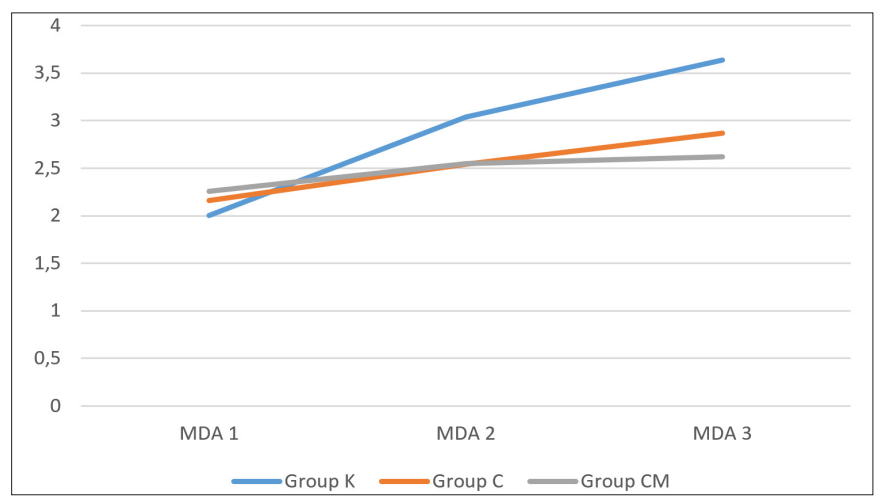

Figure 3. Comparison of MDA (malondialdehit) values in the groups (MDA 1:before induction ; MDA 2: just before cross clamp removal; MDA 3: after protamine infusion).
When the CC was removed, arrhythmia requiring intervention was observed in six patients in Group K, three patients in Group C, and one patient in Group CM. A statistically significant difference was determined only between the K Group and CM Group $(\mathrm{P}=0.026)$. The data are shown in Figure 4.



Figure 4. Arrhythmia requiring intervention when the cross clamp is lifted in all three groups ( ${ }^{\star} \mathrm{P}=0.026$ compared to Group $\mathrm{K}$ ).

\section{Table 5. Hemodynamic measurements obtained in three groups}

\begin{tabular}{|c|c|c|c|}
\hline & $\begin{array}{c}\text { Group K } \\
(\mathrm{n}=15) \\
(\text { mean } \pm \text { std }\end{array}$ & $\begin{array}{c}\text { Group C } \\
(\mathbf{n}=15) \\
(m e a n \pm s t d)\end{array}$ & $\begin{array}{c}\text { Group CM } \\
(\mathrm{n}=15) \\
(\text { mean } \pm \text { std })\end{array}$ \\
\hline $\begin{array}{l}\text { Mean arterial pressure } 1 \\
(\mathrm{mmHg})\end{array}$ & $81.20 \pm 19.75$ & $68.30 \pm 10.07$ & $72.10 \pm 8.86$ \\
\hline $\begin{array}{l}\text { Mean arterial pressure } 2 \\
(\mathrm{mmHg})\end{array}$ & $73.90 \pm 9.31$ & $74.40 \pm 11.42$ & $74.30 \pm 12.48$ \\
\hline $\begin{array}{l}\text { Mean arterial pressure } 3 \\
(\mathrm{mmHg})\end{array}$ & $66.40 \pm 5.13^{*}$ & $65.80 \pm 9.25$ & $68.30 \pm 6.73$ \\
\hline $\begin{array}{l}\text { Mean arterial pressure } 4 \\
(\mathrm{mmHg})\end{array}$ & $78.00 \pm 8.68$ & $70.10 \pm 6.98$ & $73.70 \pm 9.65$ \\
\hline $\begin{array}{l}\text { Heart rate } 1 \\
\text { (beats/min) }\end{array}$ & $70.9 \pm 13.8$ & $66.9 \pm 16.0$ & $72.6 \pm 11.8$ \\
\hline $\begin{array}{l}\text { Heart rate } 2 \\
\text { (beats } / \mathrm{min} \text { ) }\end{array}$ & $81.9 \pm 16.6$ & $77.5 \pm 15.2$ & $86.2 \pm 13.2^{*}$ \\
\hline $\begin{array}{l}\text { Heart rate } 3 \\
\text { (beats } / \mathrm{min} \text { ) }\end{array}$ & $88.1 \pm 19.2^{*}$ & $93.0 \pm 19.1^{* \dagger}$ & $86.8 \pm 10.8^{*}$ \\
\hline $\begin{array}{l}\text { Heart rate } 4 \\
\text { (beats/min) }\end{array}$ & $93.1+18.7^{*}$ & $99.5 \pm 16.4^{x+}$ & $100.4 \pm 16.4^{* \neq \neq}$ \\
\hline
\end{tabular}

The mean arterial pressure and the heart rate results obtained in the three groups, before incision (1), before $\mathrm{CPB}$ (2), five minutes after protamine infusion (3) and at the postoperative second hour (4) are shown in Table 5. There was no statistically significant difference between the groups $(\mathrm{P}>0.05)$.

The need for inotropes was detected in five patients in Group K, three patients in Group C, and four patients in Group CM. There was no statistically significant difference between the groups $(\mathrm{P}>0.05)$. 


\section{DISCUSSION}

This study demonstrated the efficacy of the combined application of ascorbic acid and $\mathrm{Mg}$ in the IR injury caused by $\mathrm{CPB}$ in $\mathrm{CABG}$ surgery. The main findings of the study were as follows: high-dose ascorbic acid and $\mathrm{Mg}$ were shown to prevent lipid peroxidation and arrhythmias requiring intervention.

Despite the advances in pharmacological intervention, surgical methods and CPB system in open heart surgery, ischemia due to $\mathrm{CPB}$ and reperfusion injury that develops after the removal of the CC and coronary flow is damaging to the heart. Systemic and local hypothermia, antegrade and retrograde hypothermic crystalloid or blood cardioplegia were used for intraoperative myocardial protection (12). Experimental studies aiming to protect organs against IR damage have been carried out using different surgical, pharmacological, and genetic methods. However, few of the studies that seem successful in the experimental setting have been applied clinically. The reason for this is that IR damage is too complex to be prevented by blocking a single step or mediator (13). The antioxidant system has an important role in protecting damage that could be caused by FOR. There are mechanisms in the antioxidant system for binding transition metal ions, preventing the formation of FOR, collecting or suppressing the formed radicals, breaking radical chain reactions, repairing, or removing damaged target molecules from the environment (14).

Antioxidant and free radical scavenger treatments were created to determine the overproduction of FOR and the role of antioxidant enzymes in the pathogenesis of myocardial damage due to IR (15). For this, pharmacological agents such as calcium channel blockers, antioxidant agents, melatonin, immunosuppressive agents, adenosine, glutamate-aspartate, $\boldsymbol{\alpha}$-tocopherol, methylprednisolone, ACE inhibitors, trimetazidine, and endothelin-1 receptor antagonists were used (16). Braunwald and Kloner (17) reported that the total antioxidant capacity decreased and oxidant damage occurred during the IR periods during CPB. In addition, it has been shown that the total antioxidant capacity was suppressed, and lipid peroxidation increased for 72 hours after the operation in patients with CPB. During $\mathrm{CBP}$, blood levels of vitamin $\mathrm{A}$, vitamin $\mathrm{E}$ and vitamin $\mathrm{C}$ were tested. There was a slight decrease in the vitamin $\mathrm{A}$ and vitamin E level, and a significant decrease in the vitamin $\mathrm{C}$ level during and after the operation (18). The decrease in the ascorbic acid level has been attributed to either a direct reaction with FOR, or its role in the regeneration of other antioxidants. In addition, in studies conducted with ascorbic acid, its inhibitory effect on lipid peroxidation and its protective role of the myocardium from IR damage has been demonstrated (19). In the study conducted by Dingchao et al. (20), it was shown that high-dose ascorbic acid administered intravenously at a dose of $250 \mathrm{mg} / \mathrm{kg}$ had a myocardial protective effect.

It is known that reperfusion causes ventricular fibrillation, ventricular tachycardia, idioventricular rhythm, and ventricular premature beats (21). It has been argued that the increase of FOR, which occurs in the early stage of reperfusion, affects the membrane lipids and thus the ion pumps, making the myocardium susceptible to arrhythmia (22). In the study of Seitelberger et al. (23), conducted on 120 patients, it was determined that $\mathrm{Ca}$ channel blockers decrease the number of ventricular premature complexes. In another study, it has been shown that ascorbic acid prevents AF (24), and in our study, when the CC was removed, arrhythmia requiring intervention was observed in six patients in Group K, three patients in Group C, and one patient in Group CM. Although the difference between Group K and Group CM is statistically significant, the detection of arrhythmia in a smaller number of patients compared to Group K with high-dose ascorbic acid administration and a further decrease in this number with the addition of $\mathrm{Mg}$ to ascorbic acid supports the additive antiarrhythmic effect advocated by Hearse and Tosaki (25).

One of the widely accepted theories about IR injury is the increase in FOR and intracellular free $\mathrm{Ca}$ (26). Uncontrolled increase in intracellular Ca levels causes ischemic contracture and structural changes. With the application of hypocalcemic reperfusion, and the addition of $\mathrm{Ca}$ channel blockers to the cardioplegia solution and the IV, intracellular $\mathrm{Ca}$ increase was prevented (27). $\mathrm{Mg}$ is a physiological Ca antagonist and reduces myocardial damage during IR by blocking the FOR products generated by reperfusion (28). In a study, $\mathrm{Mg}$ infused intraoperatively from the aortic root showed positive effects on ischemia, IR damage, and arrhythmia during cardiac surgery (29). Prophylactic Mg has been reported to reduce postoperative arrhythmia in patients under $\mathrm{CPB}$ (30). If arrhythmia occurs despite $\mathrm{Mg}$, it appears that the rate of recovery of these arrhythmias is then higher with other antiarrhythmic drugs (31).

During and after $\mathrm{CPB}$, it has been shown that Mg levels decrease postoperatively in up to $70 \%$ of the patients when it is not replaced, and then gradually increase until the $4^{\text {th }}$ postoperative day (32). The mechanism of the relationship between cellular $\mathrm{Mg}$ and serum $\mathrm{Mg}$ has not been fully determined. However, it has been demonstrated that measuring intracellular $\mathrm{Mg}$ concentration by radiographic microanalysis shows a $\mathrm{Mg}$ deficit in cardiac patients (33). Although the intracellular Mg level was not examined as a criterion of our study, we believe that these results are reliable as we have monitored the ionized fraction, which is physiologically 
the most important part. Studies have claimed that the perioperative $\mathrm{Mg}$ level can be reliably assessed by monitoring the ionized fraction in the serum in patients undergoing cardiac surgery (34).

FOR, which occur during myocardial IR are very reactive and although they have a lifespan that is measured in microseconds, their presence can be demonstrated in tissue using spin resonance spectroscopy (35). Oxidation of polyunsaturated fatty acids with FOR in biological systems is called lipid peroxidation, and the presence of FOR reaction in studies has been proven by the demonstration of lipid peroxidation markers (36). The most frequent method used for the determination of lipid peroxidation is the measurement of the MDA level. In our study, MDA levels obtained before and after the administration of protamine increased in all three groups compared to the preoperative MDA level, but it was found that this increase was less in Groups C and CM. MDA 2 and MDA 3 value were found to be statistically significantly lower in Group C and Group CM than in Group K. Although the increase in MDA was less in group CM compared to Group C, there was no statistically significant difference between them $(\mathrm{p}>0.05)$. These results show us that high dose ascorbic acid and an ascorbic acid-magnesium combination protects the myocardium against FOR.

Many studies have shown an increase in cardiac enzyme levels after CPB (37). In studies where antioxidant agents and $\mathrm{Mg}$ were used to prevent myocardial IR damage, cardiac enzyme levels were measured to show myocardial damage and conflicting results were obtained (38). Although there are studies showing that high dose ascorbic acid and $\mathrm{Mg}$ reduce $\mathrm{CK}-\mathrm{MB}$ release from the myocardium, the clinical significance of these results could not be determined (39). In our study, CK-MB and LDH levels obtained at the second hour postoperatively showed a statistically significant increase in all three groups compared to the preoperative values $(\mathrm{P}<0.001)$, but there was no additional finding suggesting myocardial damage during this period. There was no significant change in mean arterial pressure. Although not statistically significant, postoperative enzyme levels were lower in the CM group than in the other two groups. Therefore, we believe that CK-MB and LDH levels are not fully specific for myocardial damage, and that the value of cardiac enzymes has not been fully investigated in similar studies.

It has been argued that FOR occurs during myocardial IR at the same time as cellular Ca loading occurs, and endogenous defense mechanisms are insufficient. In our study, this opinion was supported by the increase in the level of MDA in Group K, which is a product of lipid peroxidation known to occur in the presence of
FOR. When ascorbic acid and $\mathrm{Mg}$ were used to prevent the damage caused by FOR, it was shown that lipid peroxidation and arrhythmias requiring intervention were prevented. However, there was no statistically significant difference between the groups in terms of cardiac enzyme levels and hemodynamic measurements. This result is parallel to the findings in the study by Demirağ et al. (40), where diltiazem was added to the ascorbic acid. Despite this result, we believe that advanced myocardial protection methods are required in high-risk patients with preoperative ventricular dysfunction, and the protective effect of $\mathrm{Mg}$ and high dose ascorbic acid will be reflected in clinical findings in patients with high risk. To reach a definitive conclusion on this subject, we believe that it is necessary to conduct studies involving a greater sample size and higher risk patients.

\section{Limitation of the Study}

The first limitation of this study is that it was conducted in a single center. The second limitation of this study is that the amount of intracellular magnesium could not be shown. The third limitation is that most patients were in the low to intermediate risk group according to the NYHA.

\section{CONCLUSION}

In conclusion, the combined use of high-dose ascorbic acid and $\mathrm{Mg}$ in CABG operations of low to medium risk patients, did not have a greater impact in preventing myocardial IR damage during CPB in terms of cardiac enzyme levels and hemodynamic measurements than cold blood cardioplegia. However, prevention of lipid peroxidation and arrhythmias that require intervention suggests that $\mathrm{Mg}$ and high-dose ascorbic acid may be beneficial in a high-risk patient group.

\section{ETHICAL DECLARATIONS}

Ethics Committee Approval: The study was carried out with the permission of Scientific Researches Ethics Committee of Osmangazi University Faculty of Medicine (Date: 30.06.2009, Decision No: 60).

Informed Consent: All patients signed the free and informed consent form.

Referee Evaluation Process: Externally peer-reviewed.

Conflict of Interest Statement: The authors have no conflicts of interest to declare.

Financial Disclosure: The authors declared that this study has received no financial support.

Author Contributions: All of the authors declare that they have all participated in the design, execution, and analysis of the paper, and that they have approved the final version. 


\section{REFERENCES}

1. Trachiotis GD, Weintraub WS, Johnston TS, et al. Coranary artery bypass grafting in patients with advanced left ventriculer dysfunction. Ann Thorac Surg 1998; 66: 1632-9.

2. Allman KC, Shaw LJ, Hachamovitch R, Udelson RJ. Myocardial viability testing and impact of revascularization on prognosis in patients with coronary arter disease and left ventrikular dysfonction: A meta analysis. J Am Coll Card 2002; 39: 1151-8.

3. Ozcan V, Beşogul Y, Tunerir B, et al. The effect of glutamate and aspartate on myocardial protection at cardiopulmonary bypass. Anadolu Kardiyol Derg 2004; 4: 114-9.

4. Piper MH, Meuter K, Schafer C. Cellular mechanism of ischemiareperfusion injury. Ann Thorac Surg 2003; 75: 644-8.

5. Moertel CG, Fleming TR, Creagan ET, Rubin J, O’Connell MJ, Ames MM. High dose vitamin C versus placebo in the treatment of patients with advanced cancer who have had no prior chemotherapy. N Engl J Med 1985; 312: 137-41.

6. Moukarbel GV, Ayoub MC, Abchee AB. Pharmacological therapy for myocardial reperfusion injury. Curr Opin Pharmacol 2004; 4: 47-53.

7. Dhalla NS, Elmoselhi AB, Hata T, Makino N. Status of myocardial antioxidants in ischemia-reperfusion injury. Cardivasc Res 2000; 47: 446-56.

8. Meerson FZ, Belkina LM, Sazontova TG, Saltykova VA, Arkhipenko Y. The role of lipid peroxidation in pathogenesis of arrhythmias and prevention of cardiac fibrillation with antioxidants. Basic Res Cardiol 1987; 82: 123-37.

9. Inserte J, Garcia-Dorado D, Agullo L, Paniagua A, Soler-Soler J. Urodilatin limits acute reperfusion injury in the isolated rat heart. Cardiovasc Res 2000; 45: 351-9.

10. Mak IT, Komarov AM, Wagner TL, Stafford RE, Dickens BF, Weglicki WB. Enhanced nitric oxide production during magnezyum defeciency and its role in madiating red cell glutation loss. Am J Physiol 1996; 271: 385-90.

11. Esterbauer H, Cheeseman KH. Determination of aldehydic lipid peroxidation products: malonaldehyde and 4-hidroxynonenal. Methods Enzymol 1990; 186: 407-21.

12. Josephson RA, Silverman HS, Lakatta EG, Stern MD, Zweier JL. Study of the mechanisms of hydrogen peroxide and hydroxyl free radical-induced cellular injury and calcium overload in cardiac myocytes. J Biol Chem 1991; 266: 2354-61.

13. Britton J, Pavord I, Richards K, Wisniewski A, Knox A, Lewis S. Diatery magnesium lung function, wheesing and airway hiperactivity in a random adulth population sample. Lancet 1994; 334: 356-62.

14. Becker LB. New concepts in reactive oxygen species and cardiovascular reperfusion physiology. Cardiovasc Res 2004; 61: 461-70.

15. Gao WD, Liu Y, Mellgren R, Marban E. Intrinsic myofilament alterations underlying the decreased contractility of stunned myocardium: a consequence of Ca2-dependent proteolysis? Circ Res 1996; 78: 455-65.

16. Wallerta $M$, Zieglera $M$, Wanga $X$, et al. $\alpha$-Tocopherol preserves cardiac function by reducing oxidative stress and inflammation in ischemia/reperfusion injury. Redox Biology 2019; 26: 101292-303.

17. Braunwald E, Kloner RA. Myocardial reperfusion: a doubleedged sword? J Clin invest 1985; 76: 1713-9.

18. Bulkley BH, Hutchins GM. Myocardial consequences of coronary artery bypass graft surgery: the paradox of necrosis in areas of revascularization. Circulation 1977; 56: 906-13.
19. Hsu CC, Wang JJ. L-ascorbic acid and alpha-tocopherol attenuates liver ischemia-reperfusion induced of cardiac function impairment. Transplantation Proceedings 2012; 44: 933-6.

20. Dingchao $\mathrm{H}$, Zhiduan Q, Liye $\mathrm{H}$, Xiaodong F. The protective effects of high dose askorbic acid on myocardium against reperfusion injury during and after cardiopulmonary bypass. Torac Cardiovasc Surgeon 1994; 42: 276-8.

21. Chung MK. Cardiac surgery: postoperative arrhythmias. Crit Care Med 2000; 28: 136-44.

22. Hearse DJ, Tosaki A. Free radicals and calcium: Simultaneous interacting triggers as determinants of vulnerability to reperfusion induced arrhythias in the rat heart. J Mol Cell Cardiol 1988; 20 : 213-23.

23. Seitelberger R, Hannes W, Gleichauf M, Keilich M, Christoph M, Fasol R. Effects of diltiazem on perioperative ischemia, arrhythmias and myocardial function in patients undergoing elective coronary bypass grafting. J Thorac Cardiovasc Surg 1994; 107: 811-21.

24. Baker WL, Coleman CI. Meta-analysis of ascorbic acid for prevention of postoperative atrial fibrillation after cardiac surgery. Am J Health-System Pharm 2016; 73: 2056-66.

25. Hearse DJ, Tosaki A. Reperfusion-induced arrhythmias and free radicals: studies in the rat heart with DMPO. J Cardiovasc Pharmacol 1987; 9: 641-50.

26. Bolli R, Marban E. Molecular and cellular mechanisms of myocardial stunning. Physiol Rev 1999; 79: 609-34.

27. Gao WD, Liu Y, Mellgren R, Marban E. Intrinsic myofilament alterations underlying the decreased contractility of stunned myocardium: a consequence of $\mathrm{Ca} 2$-dependentproteolysis? CircRes. 1996; 78: 455-65.

28. Woods KL, Barnett DB. Magnesium in acute myokardial infarction. BMJ. 1995; 310: 1669-70.

29. Beşogul Y, Tunerir B, Ozdemir C, Aslan R. Magnesium-flush infusion into the aortic root just before reperfusion reduces the requirement for internal defibrillation and early post-perfusion arrhythmias. J Int Med Res 2003; 31: 202-9.

30. Baradaril AG, Zeydi AE, Ghafari R, Aarabi M, Jafari M. A double-blind randomized clinical trial comparing different doses of magnesium in cardioplegic solution for prevention of atrial fibrillation after coronary artery bypass graft surgery. Cardiovascular Therapeutics 2016; 34: 276-82.

31. Kobara M, Tatsumi T, Kambayashi D, et al. Effects of ACE inhibition on myocardial apoptosis in an ischemia-reperfusion rat heart model. J Cardiovasc Pharmacol 2003; 41: 880-9.

32. Beyesdorf F, Allen BS. Myocardial protection with integrated blood cardioplegia. In: Franco KL, Verrior ED, eds. Advanced therapy in cardiac surgery, $2^{\text {nd }}$ ed. Hamilton London: B C Decker inc; 1999: 16: 201-13.

33. Horn B. Magnesium and the cardiovascular system. Magnesium 1987; 6: 109-11.

34. Armstrong SC. Protein kinase activation and myocardial ischemia/reperfusion injury. Cardiovasc Res 2004; 61: 427-36.

35. Schafer C, Ladilov Y, Inserte J, et al. Role of the reverse mode of the $\mathrm{Na}+/ \mathrm{Ca} 2+$ exchanger in reoxygenationinduced cardiomyocyte injury. Cardiovasc Res 2001; 51: 241-50.

36. Inserte J, Garcia-Dorado D, Ruiz-Meana M, et al. Effect of inhibition of $\mathrm{Na}+/ \mathrm{Ca} 2+$ exchanger at the time of myocardial reperfusion on hypercontracture and cell death. Cardiovasc Res 2002; 55: 739-48. 
37. Kroner A, Seitelberger R, Schirnhofer J, et al. Diltiazem during reperfusion preserves high energy phosphates by protection of mitochondrial integrity. Eur J Cardiothorac Surg 2002; 21: 22431.

38. Ballmer PE, Reinhart WH, Jordan P, Bühler E, Moser UK, Gey KF. Depletion of plazma vitamin C but not vitamin E in response to cardiac operations. J Thorac Cardiovasc Surg 1994; 108: 311 20.

39. Dingchao H, Zhiduan Q, Liye $\mathrm{H}$, Xiaodong F. The protective effects of high dose askorbic acid on myocardium against reperfusion injury during and after cardiopulmonary bypass. Torac Cardiovasc Surgeon 1994; 42: 276-8.

40. Demirag K, Askar FZ, Uyar M, et al. The protective effects of high dose ascorbic acid and diltiazem on myocardial ischaemiareperfusion injury. Middle East J Anaesthesiol 2001; 16: 67-79. 